KEYWORDS

Financial crisis

Globalization

Economic conditions

Developing countries

Remittances

International trade

Commodity trade

Capital movements

Economic indicators

Latin America
José Antonio Ocampo

Professor at Columbia University,

Former Executive Secretary of ECLAC,

Former Minister of Finance and

Public Credit,

Colombia

- jao2128@columbia.edu
CEPAL REVIEW 97 • APRIL 2009

\section{The impact of the global financial crisis on Latin America}

\author{
José Antonio Ocampo
}

$\mathrm{T}$

his essay argues that while the complete lack of liquidity characterizing the most severe phase of the financial crisis unleashed in September 2008 is now a thing of the past, lending and production activity in the industrialized countries are both contracting rapidly and the financial system is still undercapitalized. Of all the external channels through which the crisis has been transmitted to Latin America, the drop in remittances is the least important. The most widespread negative effects will come from the decline in the volume of international trade and the sharp deterioration in the terms of trade for commodities. In addition, a period of very restricted external private-sector financing lies ahead. The region's economies have entered this crisis in a stronger position than in the past, mainly because public debt is lower and international reserves are large, but this will only partially mitigate the repercussions of the worst global economic crisis since the Great Depression of the 1930s. 


\section{I}

\section{Introduction}

The global economy is widely acknowledged to be going through the worst financial crisis since the Great Depression of the 1930s. Although the industrialized world may be spared a contraction in production activity as sharp as the one experienced then, it is clear that it is also passing through the deepest recession since the Second World War (the point at which a "recession" becomes a "depression" has never yet been completely clarified). The crisis is reaching every corner of the planet. Given the role of China as a mainstay of global economic dynamism in recent decades, the contraction of its exports in November and December 2008 and the virtual stagnation of its economy during the fourth quarter of that year are the clearest evidence for the depth of the global crisis.

In the case of Latin America, the markedly favourable conditions of the 2003-2007 period, resulting from an unusual combination of a financial boom, exceptionally high commodity prices and strong remittances from migrant workers, have also come to an end. A number of the region's economies were already experiencing a substantial slowdown over the course of 2008, among them Colombia, Mexico, the Bolivarian Republic of Venezuela and almost all the smaller economies of Central America and the Caribbean. As will be seen, financing became scarcer from the third quarter of 2007, coinciding with the first phase of the financial crisis in the United States. Then in mid-2008, the fall in commodity prices began. But it was the global financial collapse of mid-September 2008 that unleashed the most profound changes by causing credit to dry up, substantially raising risk spreads, turning the fall in commodity prices into a rout and triggering a deep recession in the industrialized world. Even those Latin American economies that were still highly — not to say increasingly — dynamic

The author is grateful for the assistance provided by María Paula Carvajal in preparing this document. This essay was written for the United Nations Development Programme (UNDP) project "Estado, democracia y mercado: informe regional sobre la democracia en América Latina”. up to the third quarter of 2008, such as Brazil and Peru, ran into a wall.

With hindsight, the peculiarity of the developing world was its ability to insulate itself to some extent from the first phase of the crisis thanks to the renewed commodity price boom, the relative security its very high levels of international reserves represented for external capital and the continuing dynamism of the major Asian economies. This gave rise to a theory, propounded by the International Monetary Fund (IMF) among others, that the developing world would "decouple" from adverse trends in the industrialized countries. To use the terminology employed by Calvo (2008), however, that "Indian summer" was followed by a "storm" triggered by the global financial crisis of September 2008, whereupon it became obvious that the decoupling theory was sheer fantasy.

This essay will analyse the effects of the international crisis on Latin America. Following this introduction, the second section considers the financial crisis in the United States. The third section looks at the three external channels through which the crisis has been transmitted as the mechanisms that produced the earlier boom have been inverted. The fourth contains some considerations on the vulnerability of the region's countries and is followed by a short section of conclusions.

As will become clear in the second section, the international situation was still very fluid at the time this essay was being completed (January 2009). Having become so severely undercapitalized, the global financial sector had not found its poise and lending was continuing to contract, while economic activity and international trade were declining rapidly. What this indicates is that the intensity and duration of the crisis were still unknown. At the same time, new macroeconomic packages were being implemented, among them the second phase of the United States financial rescue plan, the fiscal programme announced by the Obama administration and the new financial rescue package announced by the British Government. Consequently, many of the observations made in this essay are subject to future contingencies. 


\section{II}

\section{The global financial crisis}

By January 2009, a year and a half had elapsed since the subprime mortgage securitization crisis erupted in the United States, and four months since the fateful week that began on Sunday 14 September 2008 with the bankruptcy of Lehman Brothers, one of the big five investment banks in the United States, and the rescue of another, Merrill Lynch, which became a subsidiary of Bank of America; Bear Stearns, having been bailed out in March, began the process of merging with J.P. Morgan Chase. The week continued with the rescue of the country's leading insurance firm, American Insurance Group (AIG), and the compulsory sale of the leading savings and loan bank (Washington Mutual) and one of the largest commercial banks, Wachovia. Many smaller institutions had already gone under and more have done so since. Furthermore, some investment banks that were still independent, such as Goldman Sachs and Morgan Stanley (in October the Japanese financial group Mitsubishi UFJ would acquire a $20 \%$ stake in the latter), became bank holding companies, thereby coming under the supervision of the Federal Reserve. On Wednesday 17 and Thursday 18 September, the United States financial system was on the verge of total breakdown and the period that came to be known as the "credit crunch" began; at its most critical stage, interbank lending and issues of commercial paper were paralysed. A series of bankruptcies also began among European banks that week, and still continues. Some British banks were already in difficulties beforehand.

As the great economic historian Charles Kindleberger has pointed out (Kindleberger and Aliber, 2005), frequent financial crises are an embedded feature of capitalism's history. Since the 1960s, furthermore, there has been a greater tendency towards financial crises of various kinds, coinciding with different global economic liberalization processes (Bordo and others, 2001). In the case of the United States, this is the third banking crisis of recent decades. The first was the Latin American debt crisis, which was skilfully managed so that its cost would be paid for by Latin America and it would not be seen for what it also was, the bankruptcy of the leading United States financial institutions. The second was the crisis in the United States savings and loan system in the late 1980s, and the third is the one being experienced now. To these might be added the major stock market collapses, including "Black Monday" in October 1987 and the bursting of the bubble in technology stocks at the beginning of the present decade, plus three episodes of acute dollar weakness, the latest of which was already in evidence before the September crisis temporarily reversed the phenomenon.

The frequency of crises is essentially due to the incapacity of financial systems to self-regulate, one corollary of which is that financial liberalization measures sow the seeds for them. The fundamental problem, as Minsky (1982) pointed out a quarter of a century ago, is that confidence tends to rise as financial booms proceed, leading financial agents to take positions that become riskier and riskier as financial liabilities outstrip current revenues or, viewed from a balance sheet perspective, as borrowing rises relative to capital (greater leverage). The logic of this mode of operating in booms is clear, as asset-price inflation allows returns to be obtained with limited capital. Booms thus end with overborrowing by all agents and undercapitalization of financial institutions, sowing the seeds of bankruptcies among both borrowers and financial intermediaries. Although this logic is recurrent, the current crisis must be the "acid test" showing that financial markets, even the most sophisticated ones, are incapable of self-regulation.

Faced with the collapse experienced by many developing countries as a result of the successive Asian, Russian and Latin American crises at the end of the last century, economic orthodoxy ended up by accepting that financial liberalization had to be accompanied by better prudential regulation and supervision (something that had already happened in a number of Latin American countries after the 1980s debt crisis). But this recommendation was not applied in the heart of global financial capitalism, where deregulation continued. Among other consequences, this led to the final removal, in 1999, of the boundaries between investment banking and commercial banking that had been established in the 1930s and, in 2004, of capital requirements for investment banks, allowing these to double their leverage levels over the following years. Furthermore, there was no regulation whatsoever of "financial innovations" such as subprime mortgages, the securitization of these or the proliferation of financial 
derivatives, particularly the new type of credit insurance that became known as credit default swaps. Nor was there any attempt at controlling the ever-greater array of off-balance sheet financial assets in the hands of even the most heavily regulated institutions (banks), while new intermediaries such as hedge funds were completely unregulated.

On top of all this, many non-bank agents began to specialize in maturity transformation, i.e., issuing bonds to raise short-term funds and then using these to make long-term loans or investments, thus creating a kind of "shadow banking system". This is a function that has traditionally been assigned to commercial banks and that becomes very problematic during crises. Bank runs are one of its most disastrous manifestations, but while this problem has not been wholly absent during the recent crisis, it has tended to disappear as deposit insurance has become widespread. However, since non-bank agents do not have access to this insurance, which in any case is limited in its coverage, the problem has now been manifested in massive withdrawals from mutual funds, hedge funds and the like.
The initial responses of the economic authorities centred on improving liquidity provision facilities and lowering central bank intervention rates, i.e., on effectively discharging their function as lenders of last resort. Measures to provide access to Federal Reserve discount window loans were first announced in mid-August 2007, shortly after the market in mortgagebacked financial securities began to collapse (figure 1 shows one aspect of this collapse, in the market for securitized commercial paper). In September 2007, the Federal Reserve cut interest rates for the first time. Of the world's major central banks, the Federal Reserve has been aggressive on both fronts, as has the Bank of England, while the European Central Bank has taken a much more conservative line. Over time, credit facilities proliferated and could be used by a range of intermediaries who had never had access to them before. The first step in this direction was taken in the United States in March 2008 as a result of the bankruptcy of Bear Stearns, when investment banks were allowed to access specific Federal Reserve lending facilities.

FIGURE 1

United States: commercial paper in circulation

(Billions of dollars)

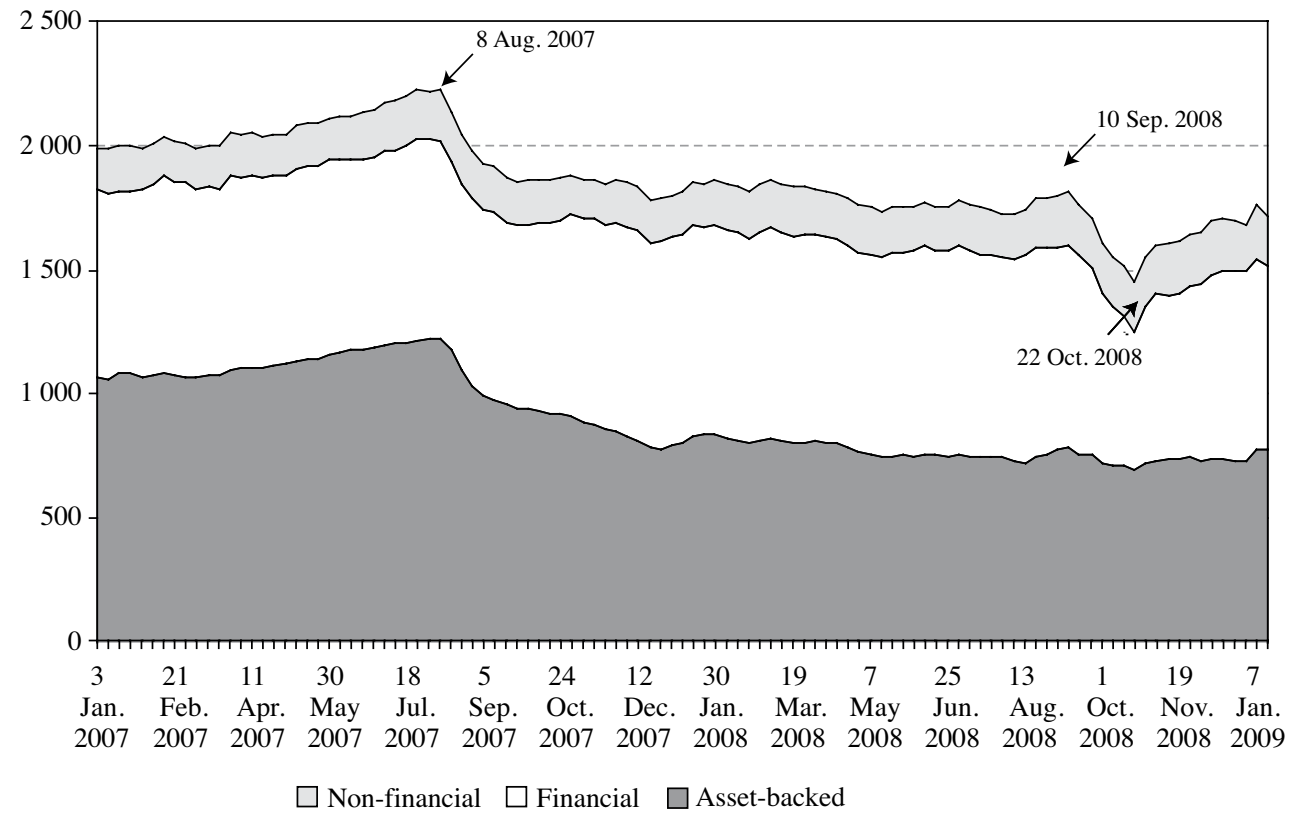

Source: Federal Reserve System, Washington, D.C. 
In the first phase of the crisis, which lasted from mid-August 2007 until the Bear Stearns bankruptcy in March 2008, the mortgage-backed securities market deteriorated sharply. The fact that many of these securities were held by financial intermediaries, and did not necessarily appear on their balance sheets, contributed to an atmosphere of mutual distrust regarding the quality of their portfolios which in time was to become the most troublesome factor in the crisis. The use of credit lines created by the Federal Reserve was moderate to begin with but began to pick up in March 2008, a month that may thus be seen as marking the start of a second phase in the crisis. At the same time, the amount of government securities held by the Federal Reserve and not lent out to private agents declined, allowing it to maintain the total size of its portfolio (see table 1). Interest rates were cut very sharply up to March 2008 (by between three and four percentage points), and these cuts fed through to short-term Treasury securities, the interbank market and deposit and lending rates in the banking system, but rates in the capital markets (corporate bonds and those of state and local governments) and those for mortgages remained practically unchanged (see table 2).

The scale of the collapse in mid-September 2008, when the third phase of the crisis began, took the authorities and the market itself by surprise. As lending seized up, the central bank took some completely unexpected measures, including the decision to purchase commercial paper through a limited liability company (actually a fund administered by the Federal Reserve Bank of New York) whose assets are backed by the Federal Government. This was the mechanism that had been designed since March to manage the Bear Stearns portfolio and that was to be used to manage that of AIG. With these measures, the policy focus switched from shoring up liquidity in the system to reactivating lending. This goal gradually came to include lower interest rates on commercial credits (for vehicle purchases, education and credit cards) and mortgages.

One consequence of this was the large-scale creation of new credit facilities increasingly oriented

TABLE 1

Portfolio of the Federal Reserve

(Billions of dollars)

\begin{tabular}{|c|c|c|c|c|c|c|}
\hline Week ending & $\begin{array}{l}8 \text { Aug. } \\
2007\end{array}$ & $\begin{array}{l}2 \text { Jan. } \\
2008\end{array}$ & $\begin{array}{l}12 \text { March } \\
2008\end{array}$ & $\begin{array}{l}10 \text { Sept. } \\
2008\end{array}$ & $\begin{array}{l}12 \text { Nov. } \\
2008\end{array}$ & $\begin{array}{c}28 \text { Jan. } \\
2009\end{array}$ \\
\hline Total credit & 850.6 & 891.7 & 869.2 & 888.3 & 2198.2 & 1989.9 \\
\hline Holdings of non-borrowed federal securities & 787.3 & 724.1 & 697.5 & 361.7 & 271.2 & 376.2 \\
\hline \multicolumn{7}{|l|}{ Credit and portfolio holdings acquired } \\
\hline from private sector & 22.3 & 102.0 & 130.5 & 428.1 & 1313.4 & 1105.4 \\
\hline Traditional credit ${ }^{\mathrm{a}}$ & 22.3 & 62.0 & 70.5 & 132.9 & 193.8 & 89.5 \\
\hline Term auction credit & & 40.0 & 60.0 & 150.0 & 415.3 & 415.9 \\
\hline Federal securities term facility & & & & 115.9 & 200.0 & 125.1 \\
\hline Facilities for investment banks & & & & & 64.9 & 32.1 \\
\hline Asset-backed commercial paper & & & & & 80.2 & 14.6 \\
\hline Credit to AIG & & & & & & 38.3 \\
\hline Other & & & & & 82.3 & 0.0 \\
\hline Net commercial paper portfolio holdings & & & & & & \\
\hline in limited liability companies & & & & & 249.9 & 316.2 \\
\hline Net portfolio of Maiden Lane ${ }^{b}$ & & & & 29.3 & 26.9 & 27.0 \\
\hline Net portfolio of Maiden Lane II and III ${ }^{\mathrm{c}}$ & & & & & & 46.7 \\
\hline Assets denominated in foreign currencies and others & 41.8 & 66.6 & 42.4 & 99.6 & 615.0 & 510.3 \\
\hline (Central bank liquidity swaps) & & & & & & 465.9 \\
\hline Float & -0.9 & -1.0 & -1.2 & -1.0 & -1.5 & -2.0 \\
\hline
\end{tabular}

Source: Federal Reserve System, Federal Reserve Statistical Release, H.4.1, Washington, D.C., 2009.

a Operations with repurchase agreements, primary, secondary and seasonal credit and overnight lending of Treasury securities.

b Limited liability company created to administer the Bear Stearns portfolio.

c Limited liability company created to administer the AIG portfolio. 
TABLE 2

United States: selected interest rates

\begin{tabular}{|c|c|c|c|c|c|c|}
\hline Week ending & $\begin{array}{l}10 \text { Aug. } \\
2007\end{array}$ & $\begin{array}{l}28 \text { March } \\
2008\end{array}$ & $\begin{array}{l}12 \text { Sept. } \\
2008\end{array}$ & $\begin{array}{l}31 \text { Oct. } \\
2008\end{array}$ & $\begin{array}{l}16 \text { Jan. } \\
2009\end{array}$ & $\begin{array}{l}23 \text { Jan. } \\
2009\end{array}$ \\
\hline \multicolumn{7}{|l|}{ Intervention rates } \\
\hline Federal Funds & 5.25 & 2.18 & 1.99 & 0.82 & 0.10 & 0.20 \\
\hline Discount & 6.25 & 2.50 & 2.25 & 1.68 & 0.50 & 0.50 \\
\hline Interbank (Libor) & 5.43 & 2.67 & 2.82 & $4.70^{\mathrm{a}}$ & 1.11 & 1.14 \\
\hline \multicolumn{7}{|l|}{ Treasury securities } \\
\hline 1 month & 4.82 & 1.22 & 1.53 & 0.28 & 0.04 & 0.03 \\
\hline 10 years & 4.79 & 3.52 & 3.66 & 3.92 & 2.30 & 2.56 \\
\hline $\begin{array}{l}\text { 3-m. certificates of deposit } \\
\text { (secondary market) }\end{array}$ & 5.43 & 2.74 & 2.79 & 3.45 & 0.85 & 1.05 \\
\hline Preferential loans & 8.25 & 5.25 & 5.00 & 4.43 & 3.25 & 3.25 \\
\hline \multicolumn{7}{|l|}{ Corporate bonds } \\
\hline AAA & 5.78 & 5.51 & 5.46 & 6.42 & 4.89 & 5.10 \\
\hline BAA & 6.66 & 6.93 & 7.05 & 9.49 & 7.97 & 8.15 \\
\hline State and local government bonds & 4.59 & 4.96 & 4.54 & 5.35 & 4.80 & 5.13 \\
\hline Conventional mortgages & 6.59 & 5.85 & 5.93 & 6.46 & 4.96 & 5.12 \\
\hline
\end{tabular}

Source: Federal Reserve System, Federal Reserve Statistical Release, H.15, Washington, D.C., 1997.

a Week ending 15 September 2008.

towards all agents in the market: commercial and investment banks were now joined by mortgage intermediaries, mutual funds and even hedge funds. Federal Reserve lending to the private sector and acquisitions of private-sector assets increased by almost US\$ 900 billion between the week ending 10 September and the week ending 12 November, when the latter peaked. On top of this were the credit swaps granted to other central banks around the world. In this period of two months and a few days, the total Federal Reserve portfolio increased by US\$ 1.3 trillion (just over 9\% of GDP). These assets were financed out of government deposits held in the Federal Reserve and surplus bank reserves deposited there (one of the manifestations of the hoarding of liquidity throughout the world), which had now become interest-bearing. Given that bank reserves form part of the monetary base, the latter grew by $70 \%$ between August and November. Much the same happened, albeit on a smaller scale, at other central banks in the industrialized countries.

These central bank measures were supplemented by bank rescue programmes led by various governments. Initially, there was a lack of coordination among authorities. In the United States, the ruling party opposed the US\$ 700 billion rescue package presented by the Bush administration, which was ultimately passed by Congress in early October thanks to opposition support. In Europe, governments announced a series of competing initiatives, particularly where deposit insurance was concerned. Generally speaking, the measures introduced by the United Kingdom on 7 October set the agenda for the rescue plans. The primary focus was on using public money to capitalize financial institutions, which in some cases has meant compete nationalization (including that of the mortgage giants Fannie Mae and Freddie Mac and the AIG group in the United States). The second measure was the expansion of deposit insurance and State guarantees for certain credit lines, particularly interbank ones, while the third consisted in creating funds to purchase "toxic assets". Although this was at the heart of the package originally approved in the United States, it was subsequently abandoned as an instrument owing to the difficulties of implementing the purchase of complex and heterogeneous securities. The Citibank rescue announced in late November 2008 and the new British package of January 2009 represent a middle way between the second and third type of measures described above, with governments extending a public 
guarantee to excess losses deriving from toxic assets still held by financial institutions (or a portion of them in the case of Citibank). Oddly enough, until January 2009 the rescue packages did not include relief for borrowers (particularly poor mortgage holders) and nor, despite pressure from some members of the United States Democratic Party, had there been any changes to the bankruptcy law to allow at least smaller mortgages to be renegotiated.

The measures applied have served to correct some of the most glaring distortions generated by the financial collapse of mid-September. After rising by almost two percentage points in the month following the crisis, the interbank interest rate tended to normalize from mid-October onward (see table 2). Issues of commercial paper recovered from the low point of 22 October (see figure 1), while pressure on Federal Reserve lending facilities eased from midNovember (see table 1). The rate of monetary base creation declined but remained high, so that between August 2008 and January 2009 a total of US\$ 855 billion was issued, equivalent to just under $6 \%$ of United States GDP. ${ }^{1}$

Meanwhile, contrary to the policy objective, there was a flight to quality originally manifested in lower interest rates on very short-term Treasury bills, which became a proxy for money, but this process coincided with a rise in market rates (or, what comes to the same thing, a significant increase in all risk spreads). From November, however, all interest rates began to fall, although those on long-term Treasury securities fell by far the most. Taken all together, while Federal Reserve rates have fallen by 5 to 6 percentage points since mid-August 2007, some are still higher than they were then (lower-rated corporate bonds and state and local government bonds) and others have fallen only modestly (highly rated corporate bonds).

This means that, although United States policy did enough to overcome the complete lack of liquidity that characterized the third phase of the crisis, as of January 2009 it had not succeeded in reactivating lending, which instead began to contract across the board in the closing months of 2008, when bank lending also began to be affected. Injecting public capital into banks has been a vital means of restoring some stability to the system, but as of early 2009 it was obvious that this process was not over and could

\footnotetext{
${ }^{1}$ According to the Federal Reserve H.3 series, the monetary base was US $\$ 1,698$ billion in the last two weeks of January 2009, or a little over double the August 2008 figure of US\$ 843 billion.
}

end in the complete nationalization of a very large number of institutions, especially in Great Britain but also in the United States and some countries of continental Europe. At the same time, it is not clear that this capitalization is sufficient to ensure more dynamic lending in the absence of a recovery in economic output.

Economic activity, meanwhile, has plummeted, with the industrialized countries seeing a $5 \%$ to $6 \%$ annualized rate of decline in the last quarter of 2008 and the first quarter of $2009 .^{2}$ There is a consensus among analysts that the effectiveness of monetary policy in the United States is very limited and that the country is actually in a "liquidity trap", manifested most particularly in the hoarding of the most liquid securities (including the depositing of commercial banks' excess reserves with the Federal Reserve) and in the strong demand for short-term Treasury securities. For this reason, attention has turned to the unconventional monetary measures mentioned earlier, whose focus is squarely on reactivating and reducing the cost of lending, and on fiscal packages. The United States has announced the largest of these, worth US\$ 800 billion (just under $6 \%$ of GDP). In other countries, central banks have continued with the task — still incomplete in Europe - of lowering interest rates.

One way of summing up recent events is to say that the third phase of the crisis, characterized by a total liquidity freeze in the financial system, has been followed since November by a fourth in which this problem has disappeared but financial institutions remain severely undercapitalized and credit is still very restricted, and whose dominant feature is the collapse of production activity in the industrialized countries, which have dragged the rest of the world down with them.

The situation in 2009 will depend on how these issues evolve. Most projections in late 2008 saw the economies of the industrialized countries, led by the United States, taking a turn for the better in the second half of this year. This is an optimistic scenario. The experience of the past in the developing world, like the Great Depression in the United States and Japan's "lost decade" of the late twentieth century, indicate that in crises like the present one that involve deleveraging and radical balance sheet adjustments,

\footnotetext{
2 Figures announced on 30 January showed United States GDP falling at a rate of $3.8 \%$ in the last quarter, but analysts expect this to be revised down yet further.
} 
the recessionary effect tends to be powerful and long-lasting. The only forecast for 2008 that proved accurate was the pessimistic scenario published by the United Nations, according to which the recession would last throughout 2009 , with a fall of $1.5 \%$ of GDP in the industrialized countries and $0.4 \%$ in the world as a whole (United Nations, 2009, table I.1). Given recent economic activity data (including those showing a marked slowdown in the Chinese economy in the fourth quarter of 2008), even this scenario now looks optimistic. Even the IMF (2009), usually among the most optimistic of institutional forecasters, stated in late January that global GDP would fall by $0.6 \%$ at market prices, a cut of almost two percentage points from the estimates it had given out just two months earlier. Private-sector forecasters are even more pessimistic.

It should be stressed that one of the main problems throughout the crisis has been the lack of coordination between the international authorities, with the striking exception of the measures applied by central banks to improve liquidity provision. One of the most recent illustrations of this failure of coordination has been the lack of consensus in Europe concerning the need to implement a more expansionary fiscal policy. In any event, it must be remembered that Europe has better automatic stabilizers than the United States (more generous unemployment insurance in particular) and that the onus is therefore on the latter to adopt ambitious discretionary fiscal measures. There has also been a great deal of discussion as to whether or not fiscal packages should focus on higher spending, with its guaranteed effects on aggregate demand, or include tax measures whose effects on aggregate demand are more uncertain.

Again, it has never been clearer that institutional improvements are needed to coordinate global macroeconomic policies and manage financial globalization. In fact, the crisis has also revealed a need to create new regulatory institutions in Europe and even the United States, given the institutional complexity of the latter's prudential regulatory and oversight system, involving as it does a whole host of federal and state agencies.

\section{III}

\section{The external channels of crisis transmission}

As was noted in the introduction to this essay, the strong growth experienced by Latin America in 20032007 resulted from the unusual combination of a financial boom, rising commodity prices and a high level of remittances from migrant workers. It was thus the reversal of these positive trends that turned these factors into external channels transmitting the crisis to the region.

\section{Remittances}

Of the three channels referred to, information on migrant workers' remittances is the most fragmented. Nonetheless, a review of Latin American balance-ofpayments statistics makes it clear that the period of rapid remittance growth ended in 2006. Remittances have increased more slowly (by an average of $3 \%$ ) over the past two years, with a moderate contraction in Mexico in 2008. In this case, the fall-off in United States construction activity was the most important crisis transmission channel for migrant workers, since a substantial proportion of workers in the home-building sector are Mexican migrants (13.8\%, or almost three times the $5.1 \%$ share of Mexican workers in the United States labour force) (J.P. Morgan, 2008). The decline of construction in Spain, a very important destination for Colombian and Ecuadorian migrants, may have had a similar effect.

However, it seems unlikely that there will be a large decline in remittances overall. World Bank forecasts for 2009 see them stagnating instead (Ratha, Mohopatra and $\mathrm{Xu}, 2008$ ). Furthermore, the purchasing power of remittances will tend to increase if the currencies of the recipient countries depreciate. Thus, curiously enough, continuity of remittances could have a stabilizing effect on household consumption.

\section{International trade}

The volume of world trade increased by $9.3 \%$ a year during the recent 2003-2006 boom, more than twice as fast as world GDP at market prices (3.8\%) (United 
Nations, 2009, table I.1). However, the growth rate of trade volumes has been very sensitive to the business cycle, and thus more volatile than that of world GDP. Accordingly, international trade has acted as an amplifier of both upturns and downturns in production activity. Trade growth fell substantially in 2007 and 2008, so that by September 2008 it stood at just $2 \%$ (United Nations, 2009, figure I.9). In fact, the partial data available indicate that world trade contracted in the fourth quarter of 2008. Forecasts from the World Bank (2009, table I.1) are for a 2.1\% drop in 2009, while the pessimistic scenario from the United Nations (2009, table I.1) shows a 3.1\% decline.

The contraction in trade volumes will be the main crisis transmission mechanism for the countries of Latin America and the Caribbean as a whole, but it will particularly affect those whose export structure is dominated by manufactures and services, i.e., Mexico, Central America and the Caribbean. In turn, commodity price trends will be the determining factor for South American exports.

In recent years, the world economy has experienced the most spectacular commodity price boom in over a century, whether measured by duration (five years) or intensity and breadth (World Bank, 2009, chapter 2). As table 3 shows, however, the boom was much stronger for mining products, including energy commodities, than for agricultural products. This is manifested in the fact that at their peak, generally in the second quarter of 2008, real mineral prices were far higher than in the 1970s (this was even truer of energy commodities than of metals). Agricultural commodities, on the other hand, barely reached the levels of that period.

One consequence of this was that, in the developing world as a whole, mining commodity exporters saw by far the largest terms-of-trade improvements, while the terms of trade of agricultural exporters held more or less steady and those of manufactured goods exporters worsened (United Nations, 2009, figure II.6). In Latin America, the most marked improvements in the terms of trade were recorded in the Andean countries, from the Bolivarian Republic of Venezuela to Chile, all major exporters of mining products, ${ }^{3}$ while Argentina, Brazil and Paraguay, which are exporters of agricultural commodities, saw only small improvements, even in 2008. Meanwhile, all the Central American countries plus Uruguay, which are heavily reliant on oil imports, saw their terms of trade worsen, while in Mexico, which combines mainly manufacturing exports with external sales of oil, they improved slightly (see figure 2).

\footnotetext{
${ }^{3}$ Some commentators do not include Colombia in this pattern, but two fifths of that country's export basket are in fact energy commodities (oil and coal) and metals (nickel and gold).
}

Real commodity prices

(Deflated by manufacturing price index, 1945-1980=100)

\begin{tabular}{lcccrrr}
\hline & $\begin{array}{c}\text { Total } \\
\text { non-oil }\end{array}$ & $\begin{array}{c}\text { Agriculture } \\
\text { total }\end{array}$ & $\begin{array}{c}\text { Tropical } \\
\text { agriculture }\end{array}$ & $\begin{array}{c}\text { Other } \\
\text { agriculture }\end{array}$ & Metals & Oil \\
\hline $1945-1970$ & 98.4 & 98.9 & 100.1 & 97.5 & 96.4 & 64.6 \\
$1971-1980$ & 104.1 & 103.0 & 99.6 & 106.4 & 109.4 & 192.1 \\
$1981-1990$ & 81.1 & 75.5 & 63.1 & 88.2 & 106.6 & 246.3 \\
$1991-1997$ & 75.3 & 73.7 & 57.9 & 89.9 & 82.4 & 139.5 \\
$1998-2003$ & 69.4 & 67.0 & 50.7 & 83.6 & 80.4 & 193.7 \\
2004 & 75.1 & 69.1 & 52.8 & 85.7 & 102.8 & 290.7 \\
2005 & 80.3 & 72.1 & 59.5 & 84.9 & 118.3 & 410.7 \\
2006 & 96.0 & 76.1 & 63.8 & 88.5 & 187.8 & 487.0 \\
2007 & 102.4 & 80.7 & 69.7 & 91.9 & 202.3 & 518.7 \\
2008 -I & 121.0 & 100.8 & 94.2 & 107.5 & 214.0 & 687.3 \\
2008 -II & 123.3 & 102.1 & 99.1 & 105.0 & 221.5 & 860.7 \\
2008 -III & 112.7 & 94.2 & 88.5 & 100.0 & 198.1 & 810.0 \\
2008-Oct. & 87.9 & 77.3 & 66.6 & 88.2 & 137.0 & 503.4 \\
2008-Nov. & 80.3 & 72.6 & 58.3 & 87.0 & 116.3 & 374.2 \\
\hline
\end{tabular}

Source: José Antonio Ocampo and María Ángela Parra, "The terms of trade for commodities in the twentieth century", CEPAL Review, No. 79 (LC/G.2200-P), Santiago, Chile, April 2003, updated by the author from the same sources. 
FIGURE 2

Latin America and the Caribbean (selected countries): terms-of-trade gains and losses

(Percentages of GDP)

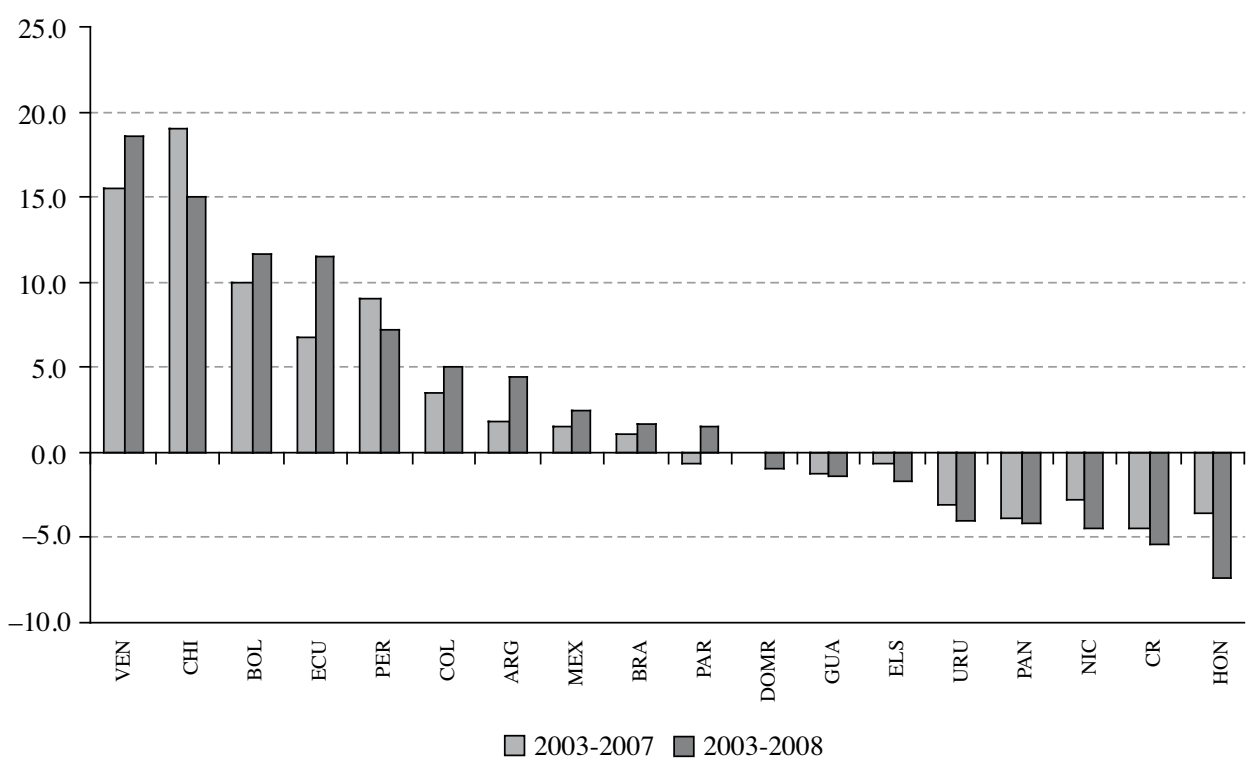

Source: prepared by the author on the basis of data from the Economic Commission for Latin America and the Caribbean (ECLAC).

This difference between mining and agricultural commodities indicates that the factors determining prices in the two groups of products are very different. In the case of energy and mining products, the key factor has been the low rate of investment resulting from weak market prices for commodities of this type between the mid-1980s and the early 2000s. Prices then rose sharply because of the high demand generated by rapid growth in developing countries over the past five years, including strong Chinese demand for metals. Investment responded positively, but in all mining projects there is a significant time lag between investment decisions and higher output. In the case of agriculture, and despite the alarm bells rung by the food crisis in the first half of 2008 , the imbalance between supply and demand was much more moderate. One important transmission channel in this case was the fact that high energy prices translated into strong prices for agricultural commodities that are used, or that replace those used, to produce biofuels (Von Braun, 2007).

Commodity prices boomed in the second half of 2007 and the first half of 2008, and dollar depreciation and financial speculation drove them still higher. Prices peaked and began to retreat around mid-2008, i.e., before the financial collapse of September that year. As the credit system crumbled, the prices of commodities, and particularly energy and mining commodities, went into freefall. Even so, by November they were still higher in real terms than they had been in the 1970s. Tropical agriculture commodities, conversely, had fallen back to their low levels of the 1990s. Price declines for temperate-zone commodities were more moderate.

The outlook for commodity prices is negative. By November they had fallen below the most recent projections of the World Bank (2009, table I.4), which were for a price drop of $25 \%$ for energy commodities and $23 \%$ for non-energy commodities in 2009 . To the cumulative decline up to November, furthermore, must be added the fresh drop in commodity prices in December.

The decline in international trade will be perhaps the most important of the channels whereby the global crisis is transmitted to Latin America. It could not be otherwise, given how much more open the Latin American economies are to trade now than in the past. The process will bring benefits, the greatest of which will come from the reversal of the terms-of-trade deterioration for oil-importing countries. The lesson of history is that opportunities also arise during crises 
because of the positive effects of a more competitive exchange rate in diversifying the production structure, but more active production development policies of the type espoused by the Economic Commission for Latin America and the Caribbean (ECLAC) (most recently in ECLAC, 2008a) will be needed if advantage is to be taken of these opportunities.

\section{Capital flows}

One of the most striking characteristics of the financial flows to the developing world over the past four decades has been the change in the factors driving booms: whereas in the 1970s it was syndicated bank lending to the public sector, this role was played in the 1990s by international bond issues and during the recent boom by portfolio capital.

The nature of financial flows during the recent upsurge can best be appreciated by reviewing the external balance sheets of the leading Latin American economies (see table 4). ${ }^{4}$ They show two striking changes. The first is an increase in assets, particularly international reserves but also direct and portfolio investments abroad, in all cases exceeding the rapid GDP growth in current dollar terms of the seven countries analysed (this almost doubled between 2003 and 2007). The second is the pronounced shift in the composition of liabilities, characterized essentially by lower borrowing and increased portfolio liabilities. The latter include investments in the region's countries by international investment funds, which also participate in local bond markets. The corollary of this process was the boom in both stock and bond markets in the countries, which in the latter case expanded by 15 percentage points of GDP from 2001 to $2007 .{ }^{5}$ Stock market valuations will be examined later on.

Two further aspects of these external balance sheets are worth highlighting. First, the combined effect of rising assets and falling liabilities meant that net external financial liabilities declined sharply, by 10 points of GDP between 2003 and 2007. This was furthermore a feature shared by all the region's seven largest economies. By late 2007, the net financial position was positive in three of them (Argentina,

\footnotetext{
${ }^{4}$ See Jara and Tovar (2008) and Ocampo (2007) for a more detailed analysis of external financing flows entering Latin America in recent years.

${ }^{5}$ Ocampo and Tovar (2008) provide a more detailed analysis of developments in the bond markets of the Latin American countries over the current decade.
}

Chile and the Bolivarian Republic of Venezuela) and close to balance in another two (Colombia and Peru). Second, the build-up of reserves looks extremely solid when compared with debt liabilities, but much less so if reference is made to all portfolio liabilities. This indicates that the reserves build-up may be seen as offsetting the accumulation of this class of liabilities. In the region's two largest countries, indeed, reserves only covered a relatively small proportion of portfolio liabilities in late 2007, while in four (Mexico and, albeit from a stronger position, Chile, Peru and the Bolivarian Republic of Venezuela) they have increased more slowly than these liabilities over recent years.

This external balance sheet improvement is unquestionably the region's greatest strength as it faces less favourable international conditions. In particular, it means that the spectre of high external public borrowing will be less of a factor in future or, to be more precise, that it will be a factor in a smaller number of countries. However, it should be emphasized that in recent years portfolio flows, the most dynamic component of external financing, have proved very volatile once again. Furthermore, as will be seen, borrowing by some private-sector firms has become a new source of vulnerability.

Throughout the boom period, the relative importance of external financing as a source of the region's balance-of-payments surpluses tended to increase. Capital-account balances, which were virtually nil between mid-2002 and mid-2004, recovered thereafter and began to outstrip current-account balances as a source of balance-of-payments surpluses. From mid-2006 to mid-2007, capital inflows become a veritable flood. In six of the region's seven largest countries (the exception being the Bolivarian Republic of Venezuela), the balance-of-payments surplus in the fourth quarter of 2006 and the first half of 2007 was close to US\$ 113 billion, some US\$ 100 billion of which was on the capital account (about two thirds was accounted for by Brazil and the rest by the other five economies) (Ocampo, 2007).

Figure 3, which tracks monthly Latin American bond issues on international markets, confirms that financing peaked between mid-2006 and mid-2007, a period when issuances were rising but unstable and the predominance of private firms increased (about $70 \%$ of all issues). In general, corporate issues are higher-cost and have shorter average maturities than government bonds and thus require more frequent debt rollovers. For these reasons, they are more vulnerable to fluctuations in capital availability. 
TABLE 4

Latin America (seven countries): external balance sheet

(Percentages of GDP at current prices)

\begin{tabular}{|c|c|c|c|c|c|c|c|}
\hline & 2001 & 2002 & 2003 & 2004 & 2005 & 2006 & 2007 \\
\hline \multicolumn{8}{|l|}{ Assets } \\
\hline Total $^{\mathrm{a}}$ & 26.5 & 29.7 & 31.9 & 31.5 & 31.4 & 32.4 & 37.5 \\
\hline Foreign direct investment & 5.8 & 6.9 & 7.0 & 7.2 & 7.0 & 7.5 & 7.9 \\
\hline Portfolio assets & 2.1 & 2.4 & 3.2 & 3.2 & 3.5 & 3.9 & 4.8 \\
\hline Derivatives & 0.0 & 0.0 & 0.0 & 0.1 & 0.0 & 0.0 & 0.0 \\
\hline Other investments & 12.1 & 13.3 & 13.4 & 12.6 & 11.4 & 10.8 & 12.5 \\
\hline International reserves ${ }^{\mathrm{a}}$ & 6.6 & 7.1 & 8.3 & 8.5 & 9.5 & 10.0 & 12.3 \\
\hline \multicolumn{8}{|l|}{ Liabilities } \\
\hline Total $^{\mathrm{a}}$ & 62.4 & 65.4 & 70.4 & 66.4 & 61.5 & 60.3 & 65.6 \\
\hline Foreign direct investment & 24.5 & 25.5 & 28.6 & 28.1 & 26.7 & 25.6 & 27.2 \\
\hline Portfolio liabilities & 19.8 & 20.1 & 23.1 & 22.9 & 22.8 & 23.8 & 28.0 \\
\hline Shares & 5.5 & 4.9 & 7.2 & 8.4 & 10.4 & 13.0 & 16.9 \\
\hline Debt & 14.3 & 15.2 & 15.9 & 14.5 & 12.3 & 10.9 & 11.1 \\
\hline Derivatives & 0.0 & 0.0 & 0.0 & 0.1 & 0.1 & 0.2 & 0.3 \\
\hline Other investments ${ }^{\mathrm{a}}$ & 18.0 & 19.8 & 18.6 & 15.4 & 11.9 & 10.7 & 10.2 \\
\hline Assets - liabilities & -35.8 & -35.7 & -38.4 & -34.9 & -30.1 & -27.9 & -28.1 \\
\hline Direct investment & -18.8 & -18.6 & -21.6 & -20.9 & -19.7 & -18.0 & -19.2 \\
\hline Financial & -17.1 & -17.1 & -16.8 & -14.0 & -10.4 & -9.9 & -8.9 \\
\hline Reserves as percentage of debt & 20.3 & 20.4 & 24.0 & 28.3 & 39.1 & 46.5 & 57.9 \\
\hline Reserves as percentage of portfolio liabilities & 33.1 & 35.5 & 35.9 & 37.0 & 41.6 & 42.1 & 44.0 \\
\hline Domestic capital market as percentage of GDP & 34.2 & 32.1 & 38.7 & 39.8 & 43.8 & 44.5 & 49.1 \\
\hline \multicolumn{8}{|l|}{ Financial assets - liabilities } \\
\hline Argentina & -0.3 & 19.8 & 20.1 & 22.0 & 29.5 & 26.2 & 29.0 \\
\hline Brazil & -34.9 & -36.4 & -35.2 & -31.0 & -24.1 & -23.8 & -28.9 \\
\hline Chile & -3.2 & -1.5 & 3.9 & 13.5 & 17.3 & 27.6 & 42.7 \\
\hline Colombia & -13.8 & -13.6 & -14.5 & -10.2 & -5.2 & -3.1 & -0.9 \\
\hline Mexico & -17.6 & -16.7 & -18.6 & -18.4 & -19.3 & -21.1 & -16.7 \\
\hline Peru & -29.4 & -27.9 & -26.4 & -21.3 & -14.4 & -7.6 & -6.8 \\
\hline Venezuela, Bol. Rep. of & 23.9 & 35.9 & 48.7 & 44.6 & 49.3 & 50.8 & 51.3 \\
\hline \multicolumn{8}{|l|}{ Reserves as percentage of portfolio liabilities } \\
\hline Argentina & 2.2 & -14.2 & 1.7 & 19.6 & 67.6 & 72.8 & 93.4 \\
\hline Brazil & 18.1 & 13.1 & 13.6 & 15.7 & 23.1 & 28.6 & 35.4 \\
\hline Chile & 142.4 & 145.8 & 108.3 & 98.9 & 93.3 & 98.3 & 83.6 \\
\hline Colombia & 78.8 & 88.1 & 84.2 & 91.8 & 102.7 & 96.8 & 114.6 \\
\hline Mexico & 30.8 & 41.6 & 42.7 & 39.0 & 35.8 & 30.0 & 29.0 \\
\hline Peru & 131.1 & 125.4 & 105.2 & 114.4 & 91.7 & 98.2 & 97.5 \\
\hline Venezuela, Bol. Rep. of & 131.1 & 125.4 & 105.2 & 114.4 & 91.7 & 98.2 & 97.5 \\
\hline
\end{tabular}

Source: prepared by the author on the basis of data from the International Monetary Fund (IMF), International Financial Statistics [online].

N.B.: current-dollar GDP data from the Economic Commission for Latin America and the Caribbean (ECLAC); domestic capital market data from the Bank for International Settlements. The data are for the seven largest economies (Argentina, Brazil, Chile, Colombia, Mexico, Peru and the Bolivarian Republic of Venezuela).

a The value of liabilities with the International Monetary Fund has been deducted from these accounts. 


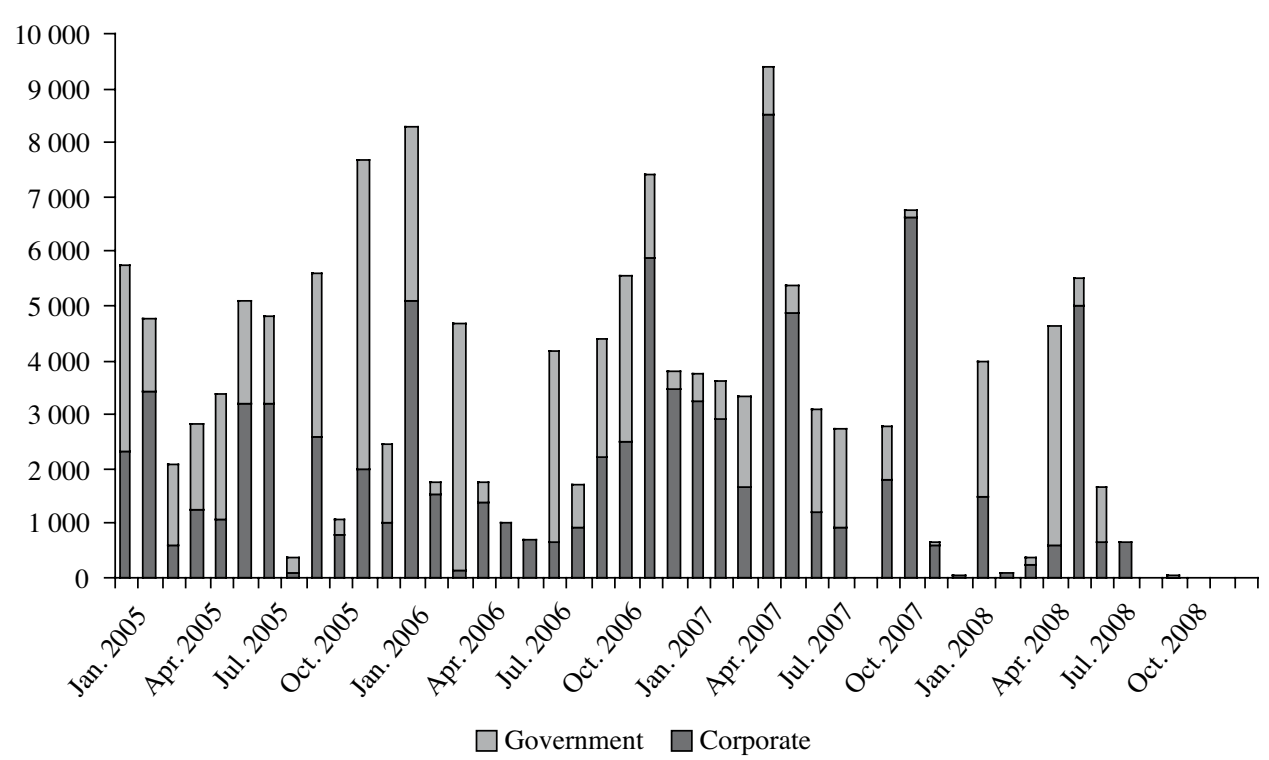

Source: Economic Commission for Latin America and the Caribbean (ECLAC) on the basis of data from J.P. Morgan.

Figure 4 shows another striking feature of the boom period: the large reduction in external financing costs. From mid-2004 onward, country risk spreads on Latin American bonds, like those of emerging markets generally, were systematically lower than they had been before the Asian crisis. Furthermore, having initially been wider than the emerging market average, these spreads tended to approach that average. Meanwhile, although Federal Reserve interest rates also rose over the period (from September 2004 onward), the rates on long-term Treasury securities, which provide a benchmark for price-setting in international bond markets, were not greatly affected. The result was that falling spreads translated into a sharp decline in external financing costs, from $10 \%$ in the first half of 2004 to just under 7\% at their lowest point in April and May 2007. This trend altered on two occasions: in March 2005, because of rising interest rates in all markets, and in the second quarter of 2006, reflecting a more specific emerging-market shock whose epicentre was Shanghai. It should be added that the reduction in financing costs was experienced right across the region, although it was moderate in the two countries already considered low-risk before the boom (Chile and Mexico).
This financial market "exuberance" was transmitted to the Latin American economies via three different channels. In the first place, there was the downward pressure on domestic interest rates generated by the reduction in external financing costs. A second and sometimes complementary factor was that this pressure was reflected in exchange rates. Lastly, strong risk appetite was manifested in stock market inflation. The great boom in Latin American stock markets began in mid-2004, i.e., when the country risk spreads of the region's countries began to fall rapidly. On average, stock prices in the region's seven largest economies quadrupled in dollar terms between mid-2004 and mid-2007 (see figure 5).

The international financial crisis has spread in complex ways over time and had different effects on the different countries of the region. The initial impact, during the third quarter of 2007, consisted of a large decline in capital flows and bond issues (see figure 3), a moderate increase in financing costs (see figure 4) and a likewise moderate decline in stock markets, which was quickly reversed (see figure 5). Compared to the previous market shock of May to July 2006, spreads were more volatile between July and September 2007, but the effects were diverse. Displaying a pattern that 
FIGURE 4

Latin America and emerging countries: sovereign bond yields

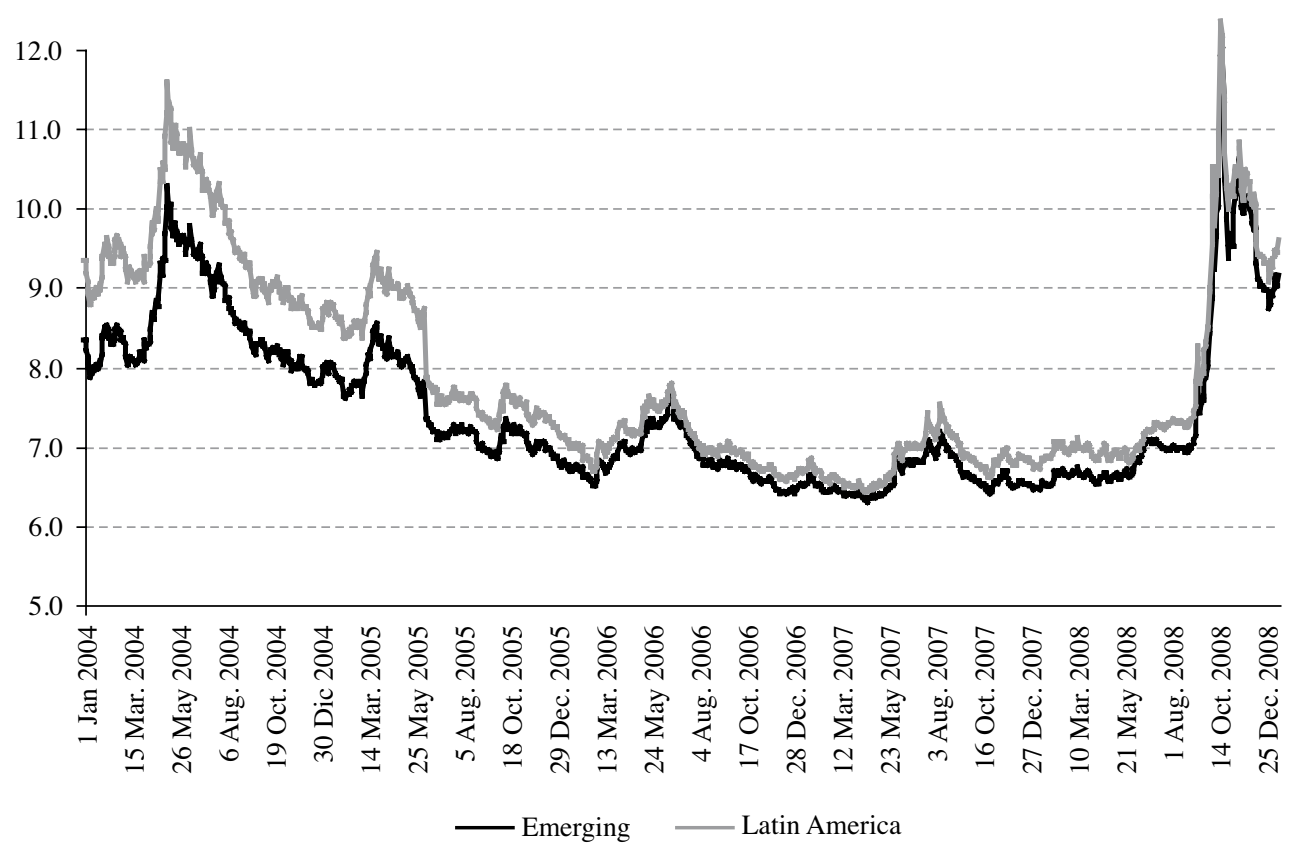

Source: Prepared by the author on the basis of data from J.P. Morgan.

FIGURE 5

\section{Stock markets}

(July 2003-June $2004=100)$

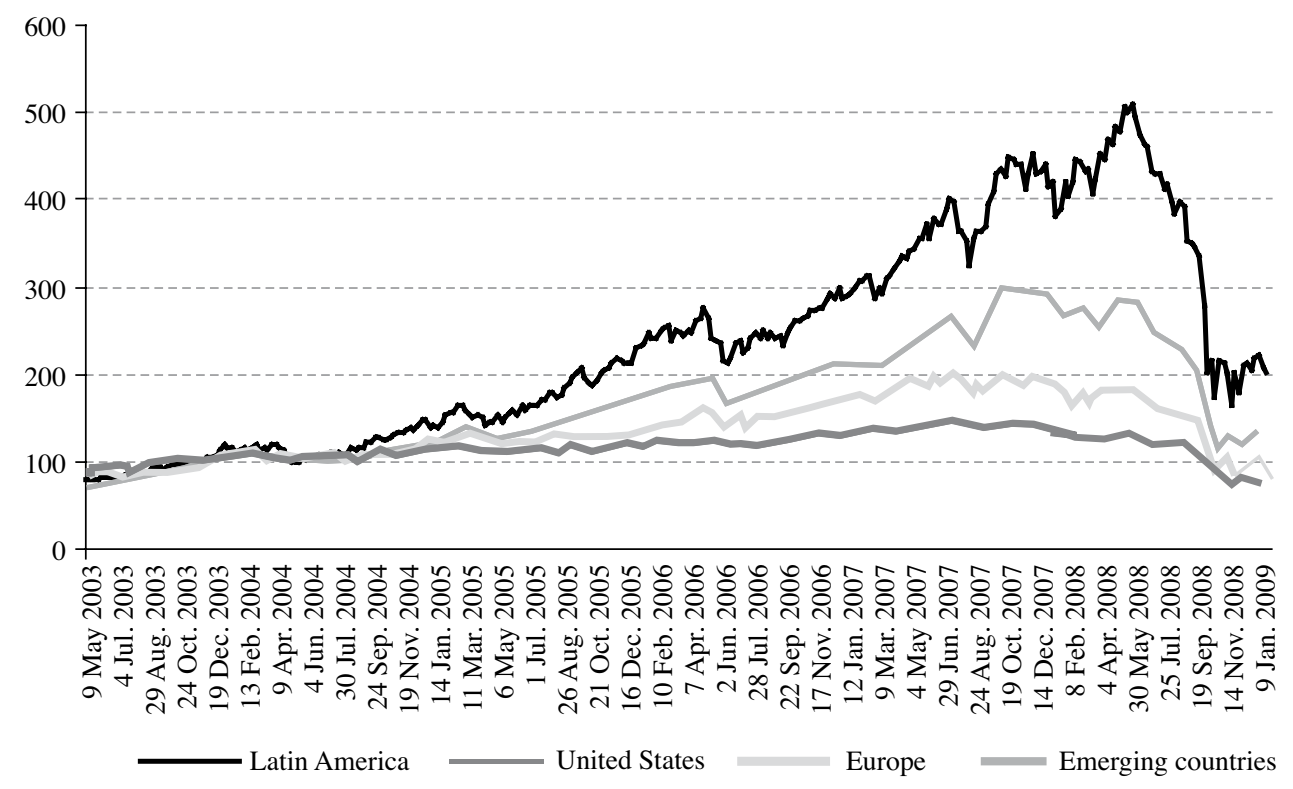

Source: Prepared by the author on the basis of data from Morgan Stanley. 
would subsequently be heightened and that reflects an element of so-called "political risk", the increase in and volatility of spreads were greatest in Argentina and the Bolivarian Republic of Venezuela. In Brazil and Colombia, meanwhile, just as in May to July 2006, exchange rates were particularly sensitive to shortterm movements in spreads; there was also a strong correlation between the two variables in Mexico, but with much lower levels of volatility. Chile and Peru were the economies least affected (see table 5).

This turbulent situation was followed, however, by an "Indian summer" in which financing costs fell back again and financing flows were renewed. The latter, however, did not rise back to their earlier levels and became more irregular, as can be seen from monthly bond issues. By contrast with the global pattern (a brief recovery in October 2007 followed by a downward trend), Latin American stock prices, measured in dollars, resumed their upward trend and actually peaked in May 2008, although this largely reflected the strong appreciation of the Brazilian real.

The new upset in the market occurred in June 2008, and thus clearly predated the financial collapse of September. In fact, it coincided with the reversal of the upward trend in commodity prices. This relationship is explained by the fact that many emerging multinationals in Latin America are producers of industrial commodities such as steel and cement. Bond emissions plummeted in June and July and disappeared from the market from August onward. Financing costs had already risen by half a percentage point by the time of the September 2008 collapse. The volatility of spreads was much the same as it had been during the shock in the third quarter of 2007. Argentina and the Bolivarian Republic of Venezuela moved further away from the other large countries, while in Brazil and Colombia exchange rates once again proved particularly unstable. Stock markets fell sharply, but prior to the September upheaval still averaged levels three and a half times as high as in mid-2004.

The collapse of mid-September 2008 dramatically heightened these tendencies. ${ }^{6}$ Lending of every kind dried up and capital departed the region via some rather unexpected channels: worldwide securities sell-offs as mutual and hedge fund deposits were redeemed in the United States, and the dismantling of carry trade operations conducted out of Japan, one of whose

\footnotetext{
${ }^{6}$ A recent essay by Bustillo and Velloso (2009) provides a detailed analysis of the effects of the international financial crisis on the Latin American economies.
}

beneficiaries had been Brazil. This caused all the Latin American currencies to depreciate sharply, while the dollar and yen appreciated on international markets. Furthermore, exchange-rate fluctuations resulted in large losses on futures markets, especially in Brazil and Mexico. The sum total of net capital outflows from Latin America during the fourth quarter of 2008 is unknown, but the loss of reserves in most of the countries is a manifestation of the phenomenon. The other effects are known with accuracy: financing costs rose substantially (see figure 4 ) and stock markets fell by much more than those in the industrialized countries (see figure 5); spreads became very volatile and their correlation with exchange-rate movements increased in all the countries (see table 5); Brazil, Chile and Mexico were now the countries with the most unstable exchange rates, while Colombia proved more stable than in earlier episodes, perhaps because its legal reserve requirement for incoming capital had reduced the volume of more volatile capital; and the gap between spreads in Argentina and the Bolivarian Republic of Venezuela and those in the other large economies of Latin America widened significantly, to 10 or more percentage points.

In line with interest rate movements in the United States (see table 2), financing costs peaked in late October (12.35\% on 23 October) before declining and tending to stabilize at between $9 \%$ and $10 \%$ from mid-December, a level not far removed from those prevailing before the boom which began in 2004 and two to three percentage points higher than those considered normal before the United States financial crisis. The greatest pressure on currency markets also arose between mid-September and late October; although currencies have depreciated less since then, markets have remained very volatile. Stock markets have also tended to stabilize, and indeed in Latin America they have done so at levels higher than those of mid-2004, by contrast with what has happened in other markets (see figure 5).

Although there appears to have been a recovery from the worst symptoms of the financial collapse associated with the complete illiquidity characterizing the third phase of the United States financial crisis, its more permanent effects persist. All current projections indicate that private capital flows will remain at low levels for the immediate future. Projections by the Institute of International Finance (2009), for example, indicate that in 2009 private lending flows into all emerging economies will be negative, by comparison with net inflows of over US\$ 600 billion in 2007, but 
TABLE 5

Latin America (selected countries): exchange-rate and risk spread volatility in periods of turbulence

\begin{tabular}{|c|c|c|c|c|c|c|c|c|}
\hline & Argentina & Brazil & Chile & Colombia & Mexico & Peru & Ven., B.R. of & EMBI + \\
\hline \multicolumn{9}{|l|}{ Risk spread volatility ${ }^{a}$} \\
\hline May 2006-Jul. 2006 & 26.2 & 19.6 & 3.6 & 27.7 & 14.7 & 10.1 & 20.9 & 16.4 \\
\hline Jul. 2007-Sep. 2007 & 60.6 & 21.9 & 14.5 & 31.6 & 15.0 & 23.5 & 64.6 & 25.0 \\
\hline Jun. 2008-12 Sep. 2008 & 58.5 & 24.2 & 7.0 & 24.3 & 22.1 & 24.0 & 48.0 & 24.5 \\
\hline 15 Sep. 2008-Jan. 2009 & 352.4 & 79.4 & 61.4 & 104.7 & 82.4 & 92.6 & 306.6 & 126.5 \\
\hline \multicolumn{9}{|l|}{ Average spreads } \\
\hline May 2006-Jul. 2006 & 362.8 & 249.3 & 81.0 & 215.4 & 134.3 & 167.5 & 207.6 & \\
\hline Jul. 2007-Sep. 2007 & 414.2 & 187.3 & 105.6 & 167.3 & 111.9 & 151.3 & 389.2 & \\
\hline Jun. 2008-12 Sep. 2008 & 632.5 & 226.5 & 173.0 & 211.5 & 168.5 & 190.1 & 623.4 & \\
\hline 15 Sep. 2008-Jan. 2009 & 1572.6 & 450.7 & 323.5 & 502.6 & 384.0 & 470.1 & 1492.2 & \\
\hline \multicolumn{9}{|l|}{ Exchange-rate volatility ${ }^{\mathrm{b}}$} \\
\hline May 2006-Jul. 2006 & 0.56 & 3.24 & 2.11 & 3.12 & 1.81 & 0.57 & 2.24 & \\
\hline Jul. 2007-Sep. 2007 & 0.78 & 2.95 & 0.91 & 4.51 & 1.21 & 0.57 & 0.00 & \\
\hline Jun. 2008-12 Sep. 2008 & 0.59 & 3.16 & 2.74 & 5.99 & 1.55 & 2.17 & 0.00 & \\
\hline 15 Sep. 2008-Jan. 2009 & 3.63 & 8.20 & 6.28 & 3.64 & 7.70 & 1.86 & 0.00 & \\
\hline \multicolumn{9}{|l|}{ Average exchange rate } \\
\hline May 2006-Jul. 2006 & 3.07 & 2.20 & 535 & 2494 & 11.16 & 3.26 & 2.59 & \\
\hline Jul. 2007-Sep. 2007 & 3.14 & 1.92 & 520 & 2041 & 10.96 & 3.15 & 2.15 & \\
\hline Jun. 2008-12 Sep. 2008 & 3.03 & 1.62 & 507 & 1818 & 10.26 & 2.89 & 2.15 & \\
\hline 15 Sep. 2008-Jan. 2009 & 3.32 & 2.23 & 628 & 2260 & 12.87 & 3.09 & 2.15 & \\
\hline \multicolumn{9}{|c|}{ Ratio between exchange rate and EMBI + } \\
\hline May 2006-Jul. 2006 & 0.789 & 0.832 & 0.796 & 0.885 & 0.755 & -0.388 & 0.477 & \\
\hline Jul. 2007-Sep. 2007 & 0.818 & 0.658 & 0.364 & 0.789 & 0.930 & 0.059 & 0.000 & \\
\hline Jun. 2008-12 Sep. 2008 & -0.145 & 0.440 & 0.752 & 0.788 & 0.177 & 0.375 & 0.000 & \\
\hline 15 Sep. 2008-Jan. 2009 & 0.751 & 0.876 & 0.901 & 0.678 & 0.901 & 0.808 & 0.000 & \\
\hline
\end{tabular}

Source: prepared by the author on the basis of data from J.P. Morgan Chase.

N.B.: EMBI $=$ Emerging Markets Bond Index.

a Standard deviation.

b Coefficient of variation.

that the large outflows of portfolio capital seen in 2008 will be stemmed. All studies suggest that the most critical problems will arise when the region's major private firms seek to roll over their debt (see, for example, J.P. Morgan, 2009). Consequently, the heavy reliance of these firms on industrial commodities and the drastic shortening of financing maturities will be the main weaknesses of the capital account.

These problems, plus the major uncertainties deriving from the still partially unresolved financial crisis in the industrialized world, suggest that the weakness of private-sector external financing will persist for some time. However, it is possible that the capital-account crisis in Latin America will be less acute than on earlier occasions because of the better starting conditions this time around in terms of reserve levels and external debt. Furthermore, one favourable side-effect of the new context has been the easing of the powerful pressures causing currencies to appreciate in a number of the region's countries during the boom. These subjects will be the main focus of the following section. 


\section{IV}

\section{The vulnerability of}

\section{the Latin American countries}

The history of Latin America since the 1970s has been marked not only by major external shocks, both positive and negative, but also by macroeconomic policies that have tended to heighten rather than mitigate the effects of these upheavals on domestic economic activity, i.e., procyclical macroeconomic policies. The fundamental problem with this behaviour is that a number of vulnerabilities arise during the favourable phases of the business cycle, essentially in the form of public- or private-sector deficits which lead to high levels of borrowing and corresponding balance-ofpayments current-account deficits, further exacerbated by overvalued national currencies. These vulnerabilities are exposed when the exceptional external conditions come to an end and severe macroeconomic adjustments have to be made in the form of fiscal tightening (involving differing combinations of spending cuts and tax increases), restrictive monetary and credit policies and large exchange-rate adjustments.

Compared with this historical pattern, it has been argued that the recent economic boom led to an important change in macroeconomic policy, reflected in the higher priority given to macroeconomic equilibria (see ECLAC, 2008c, among others). As evidence for this, the proponents of this view point to the healthier public accounts and current-account surpluses that characterized the region during the boom period.

This interpretation of recent economic history in Latin America needs to be qualified, however, in a number of ways. A far more realistic reading is the one presented by the Inter-American Development Bank (IDB, 2008), largely based on the work of Izquierdo, Romero and Talvi (2008) and agreeing with my own position in an earlier paper (Ocampo, 2007). According to this alternative view, the cause of the recent good performance was the strength of the external factors that drove the boom, since economic policy generally remained procyclical. The most important and common differences from the past were lower external borrowing by the public sector and the build-up of international reserves.

Table 6 presents a summary of developments in fiscal indicators. As can be seen, in 2008 just three countries ran a central government deficit of more than 2\%: Brazil, Colombia and the Dominican Republic. In almost all the countries, furthermore, central government debt as a proportion of GDP was substantially lower than at the beginning of the previous crisis, with the exceptions of Brazil and Colombia once again, plus Argentina and Uruguay. However, these positive fiscal results were primarily due to exceptional public-sector revenues and not spending policies, which generally remained procyclical, with some exceptions. ${ }^{7}$ The most notable of these is Chile, a country that has followed structural balance rules for its fiscal accounts for almost a decade, reinforced during the economic boom by means of two stabilization funds designed to save the fiscal surpluses generated by high copper prices: the Economic and Social Stabilization Fund and the Pensions Reserve Fund.

As table 6 shows, the GDP-elasticity of primary spending was over 1 in almost all the region's economies. According to countercyclical rules, however, spending ought to increase by significantly less than GDP during economic upturns, i.e., the GDP-elasticity should be less than 1. The exceptions, besides Chile, were El Salvador and Guatemala. Although there are other countries where elasticity was less than 1 , real primary spending growth during the boom exceeded the longterm growth rate of the economies concerned.

This procyclical behaviour of fiscal policy stands in contrast to the complex institutional apparatus introduced since the late 1990s in the form of numerous fiscal responsibility laws and newly created stabilization funds. Rule changes and the practice of earmarking resources in advance indicate that hitherto the effects of these fiscal institutions have been limited (Jiménez and Tromben, 2006).

Developments in the external accounts also reveal a pattern that is far from suggesting a policy approach designed to generate balance-of-payments current-account surpluses. Once again, the determining external factor was the sharp improvement in the

${ }^{7}$ See, in particular, IDB (2008, chapter 3 ). A study by ECLAC (2008b, chapter IV) also contains some important reflections on the subject. 
TABLE 6

\section{Latin America: fiscal indicators \\ (Percentages)}

\begin{tabular}{|c|c|c|c|c|c|c|}
\hline & \multicolumn{2}{|c|}{$\begin{array}{l}\text { Central government } \\
\text { surplus or deficit } \\
\text { (percentages of GDP) }\end{array}$} & \multicolumn{3}{|c|}{$\begin{array}{l}\text { Central government debt } \\
\text { (percentages of GDP) }\end{array}$} & \multirow{2}{*}{$\begin{array}{c}\text { Real primary } \\
\text { spending growth } \\
2003-2007\end{array}$} \\
\hline & 2007 & 2008 & 2007 & 2008 & $\begin{array}{c}\text { Change } \\
1998-2008\end{array}$ & \\
\hline Argentina & 0.6 & 1.0 & 55.7 & 48.0 & 10.4 & 11.9 \\
\hline Bolivia (Plurinational State of) & 2.3 & 3.0 & 37.1 & 30.7 & -24.4 & 5.0 \\
\hline Brazil & -2.0 & -2.6 & 32.7 & 30.1 & 5.9 & 9.0 \\
\hline Chile & 8.8 & 6.9 & 4.1 & 3.5 & -8.6 & 2.5 \\
\hline Colombia & -3.0 & -2.7 & 35.2 & 33.2 & 11.1 & 7.9 \\
\hline Costa Rica & 0.6 & -0.5 & 27.7 & 23.5 & -19.4 & 5.1 \\
\hline Ecuador & -0.1 & -0.1 & 27.5 & 22.6 & -34.4 & 10.3 \\
\hline El Salvador & -0.2 & -0.6 & 34.5 & 31.2 & -2.1 & 0.4 \\
\hline Guatemala & -1.5 & -1.2 & 21.7 & 19.3 & 2.9 & 2.9 \\
\hline Mexico & 0.0 & 0.0 & 21.1 & 20.4 & -7.4 & 5.9 \\
\hline Nicaragua & 0.6 & 0.8 & 42.2 & 34.6 & -89.6 & 6.4 \\
\hline Panama & 1.2 & -1.0 & 53.2 & 46.6 & -15.4 & 8.2 \\
\hline Paraguay & 1.0 & 0.5 & 17.3 & 12.1 & -8.4 & 4.4 \\
\hline Peru & 1.8 & 2.3 & 27.2 & 22.8 & -14.4 & 7.4 \\
\hline Dominican Republic & 0.6 & -3.2 & 19.0 & 16.7 & -1.5 & 10.2 \\
\hline Uruguay & -1.7 & -1.0 & 50.7 & 39.9 & 15.9 & 6.4 \\
\hline Venezuela (Bol. Rep. of) & 3.0 & -1.8 & 19.3 & 14.0 & -15.4 & 13.4 \\
\hline
\end{tabular}

Source: prepared by the author on the basis of data from the Economic Commission for Latin America and the Caribbean (ECLAC).

terms of trade. Figure 6 shows an estimate for the current-account balance of the region as a whole, with and without terms-of-trade adjustments. In the former case, the base year taken is the one preceding the economic boom, i.e., 2003. As can be seen, the current-account surplus was entirely due to the termsof-trade improvement. Adjusted for this variable, the current account registered a growing deficit throughout the boom period. This reached the equivalent of $5 \%$ of GDP in 2008, a much higher figure than that for the Latin American economies before the crisis of the late twentieth century.

Table 7 gives a more detailed overview. As it shows, the only economies to record a current-account surplus up to 2008 were three hydrocarbon exporters (Plurinational State of Bolivia, Ecuador and the Bolivarian Republic of Venezuela) and Argentina. Another two whose exports are based on mining commodities (Chile and Peru) ran surpluses up to 2007, but these declined sharply in 2008. As table 7 reveals, both countries were already running substantial current-account deficits in 2007 if the adjustment is made for changes in the terms of trade. Brazil followed a similar path, albeit the country's initial surplus was more modest. The only economies to show a small current-account surplus in 2008, when adjusted for the terms of trade, were Plurinational State of Bolivia and Uruguay. In the latter, the current deficit was therefore due to high prices for imported hydrocarbons. Otherwise, what this indicates is that given the collapse of mining and energy commodity prices, countries with an export base of this type will need to undergo a major adjustment process over the coming years.

One of the basic explanations for the currentaccount deterioration over the period of strong economic growth was, as formerly, the tendency towards real currency appreciation. As table 7 shows, this was particularly strong in Brazil, Colombia and the Bolivarian Republic of Venezuela, but also in a number of smaller economies (Guatemala, the Dominican Republic and Uruguay). Chile also experienced peso appreciation in real terms, although this was more moderate. The most notable exceptions here were Plurinational State of Bolivia and Peru; Argentina was also an exception until 2006, but the real-term devaluation shown in table 7 owes more to official underestimates of the inflation rate in recent 


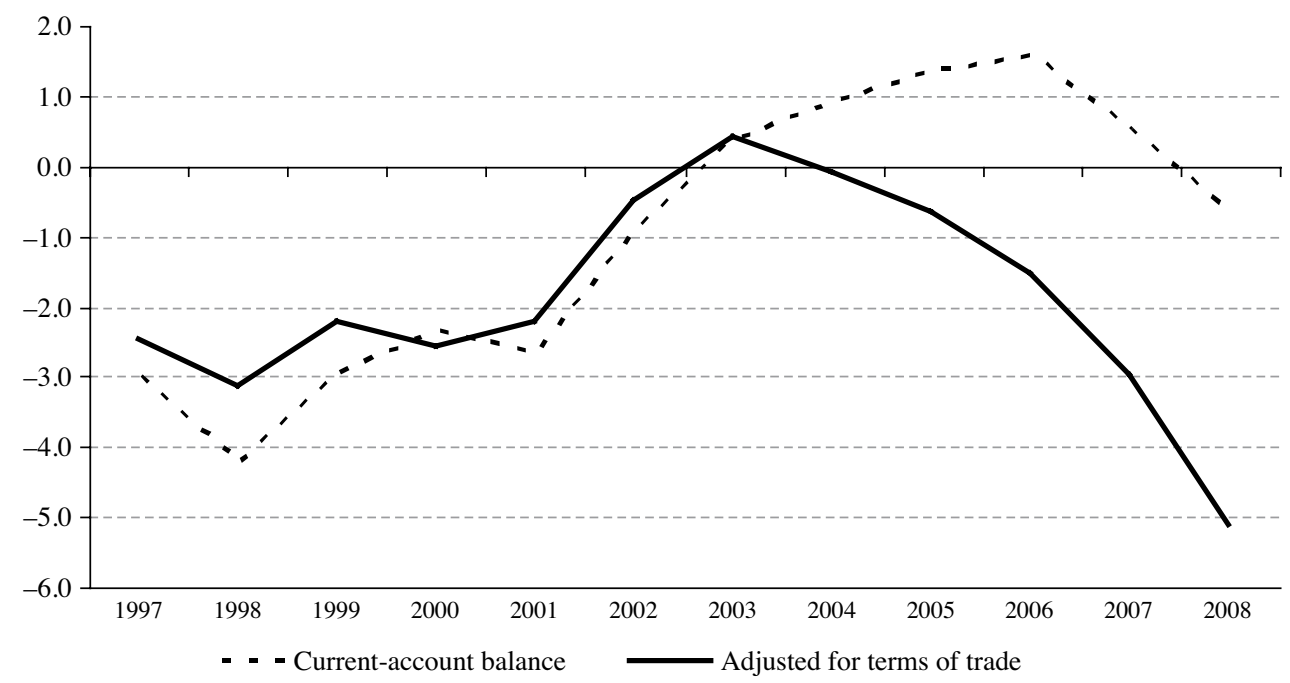

Source: prepared by the author on the basis of data from the Economic Commission for Latin America and the Caribbean (ECLAC).

years. The real-term devaluation undergone by the United States currency during the boom favoured the three dollarized economies (Ecuador, El Salvador and Panama).

Figure 7, meanwhile, reveals that the only aspects in which the Latin American economies have shown a systematic and consistent improvement in relation to the past are external public borrowing and the buildup of international reserves. To correct the effects of real exchange-rate variations on GDP, the estimates used 2000 purchasing power parity exchange rates. As can be seen, there was a substantial improvement in net external debt levels, thanks to lower borrowing up until 2006 and the build-up of international reserves since then. The reduction in public borrowing was due both to explicit fiscal policy decisions (less external financing and greater use of growing domestic capital markets) and to programmes favouring heavily indebted poor countries and the renegotiation of the Argentine debt.

The reserves build-up, meanwhile, resulted from explicit decisions to accumulate both current-account surpluses (usually generated, as we have seen, by exceptional commodity prices) and the flood of external financing. The latter is reflected in figure 8 , which calculates the build-up of reserves as a proportion of GDP in six of the seven largest Latin American economies during the three phases of plentiful external financing. As can be seen, Argentina was among the first to bring in a policy of building up reserves (the reserves deriving in this case from the current-account surplus rather than from the capital account). Other than Mexico, all the countries in the chart intervened actively in the market to accumulate some of the funds entering in the flood of external financing between mid-2006 and 2007. ${ }^{8}$ Chile and Peru did the same during the first half of 2008 , as did other countries to a lesser degree. This "fear of floating" when confronted with that surge of external capital was thus one of the great virtues of Latin American macroeconomic management during the recent economic boom (as it was, indeed, in the developing world generally), although in some cases it did not serve to prevent real currency appreciation.

As a result both of lower public-sector external borrowing and of the reserves build-up, virtually all the countries are well placed in this respect (see table 7). The main exceptions are certain Central American countries (El Salvador, Nicaragua and Panama) and, to

\footnotetext{
${ }^{8}$ In the case of Chile, the calculations include the transfer of resources to stabilization funds. The balances of these funds were also added to the international reserves total to calculate the country's external borrowing ratios.
} 


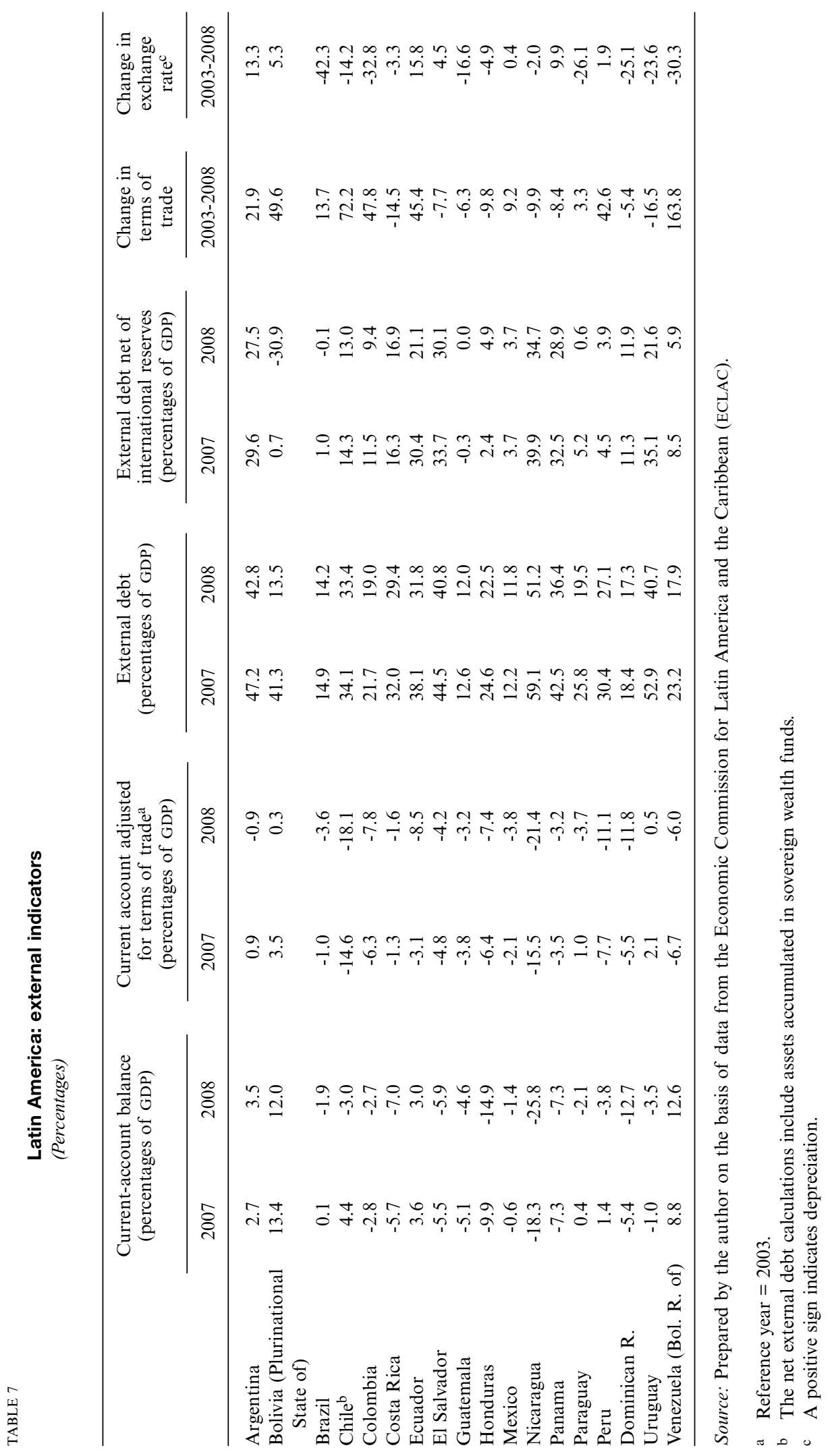


FIGURE 7

Latin America: external debt, gross and net of international reserves (2000 exchange rate)

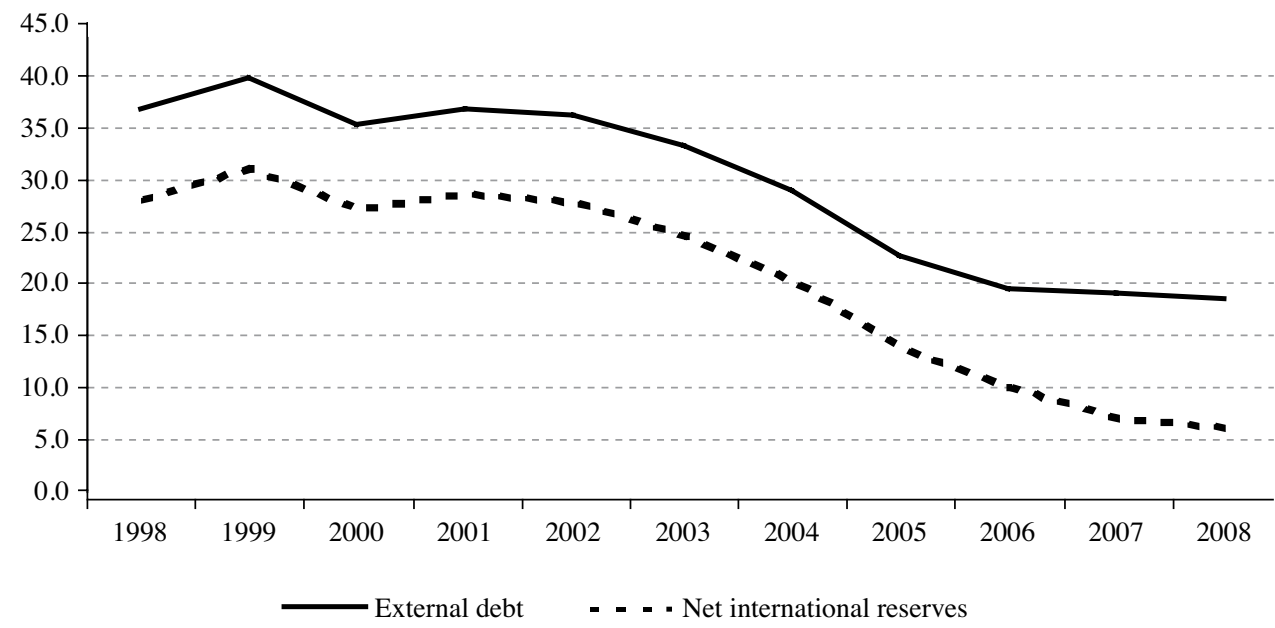

Source: prepared by the author on the basis of data from the Economic Commission for Latin America and the Caribbean (ECLAC). N.B.: In the case of Chile, includes resources in sovereign wealth funds.

FIGURE 8

Latin America (selected countries): reserves accumulated

in periods of plentiful external financing

(Percentages of GDP)

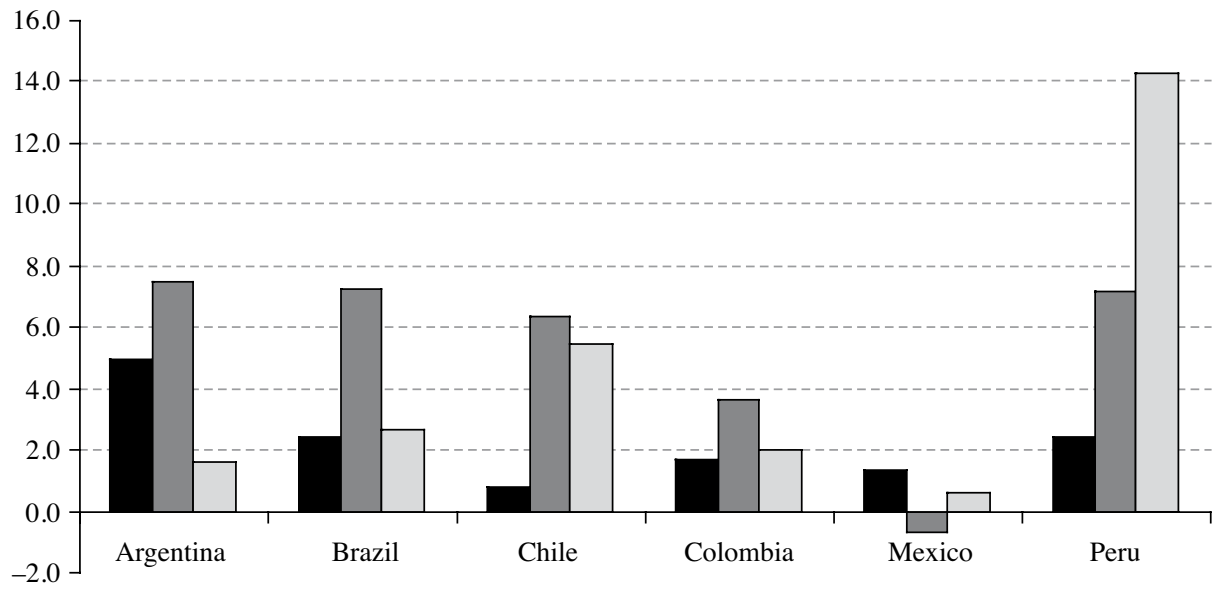

July 2004-April $2006 \quad \square$ July 2006-June $2007 \quad \square$ January-June 2008

Source: prepared by the author on the basis of data from the International Monetary Fund (IMF), International Financial Statistics [online].

N.B.: In the case of Chile, includes resources transferred to sovereign wealth funds. 
a lesser extent, South American countries that inherited a heavy external debt burden from the previous crisis (Argentina, Ecuador and Uruguay). Plurinational State of Bolivia is running large surpluses and in 2008 Brazil was in a position of virtual equilibrium.

This favourable situation as regards public and external borrowing is the region's main asset in the current crisis. Where public borrowing is concerned, with some exceptions (Brazil and Colombia being the most obvious ones) there is greater scope than in the past to adopt countercyclical fiscal policies. Chile of course has particular room for manoeuvre because it saved a substantial volume of fiscal revenues during the economic boom. In a number of economies, high levels of international reserves have been used to

\section{V \\ Conclusions}

The international crisis has had the anticipated effects on Latin America. Having been underpinned by an exceptional combination of favourable external conditions, the economic boom came to an end and all the factors that nurtured it are now working in the opposite direction. Of these, the possible decline in remittances is the least important and will be offset in several countries by real currency depreciation, which will positively affect the domestic consumption capacity of the households receiving these resources.

The greatest and most widespread repercussions of the crisis will be felt in the sphere of trade. All the countries, but especially Mexico, Central America and the Caribbean, are being affected by the contraction in real trade volumes, while the South American economies, particularly those exporting mining and energy commodities, have experience a sharp decline in their terms of trade. The fall in energy prices will partially offset the adverse effects of lower international trade in a number of small economies.

From an external financing point of view, it is possible that the most acute problems associated with the illiquidity characterizing the severest stage of the crisis (between mid-September and late October 2008) may be behind us. However, a phase of very restricted private-sector external financing, of unknown duration and intensity, still lies ahead. Multilateral financing mitigate the effects of the crisis on export sectors and private-sector firms without access to financing. During the most critical months of the crisis, they also meant that some liquidity provision policies could be applied. Central banks subsequently began to cut interest rates, a tendency that has been spreading widely as of early 2009 . Exchange rates came under pressure more rapidly than in the past, allowing the overvaluation that was a feature of several economies (Brazil, Chile, Colombia and Mexico chief among them) to be quickly corrected. These measures were supplemented by a wide range of fiscal, sectoral and social policies (ECLAC, 2009). Other than the rapid depreciation of a few currencies, however, the macroeconomic repercussions of these initiatives have so far been moderate. can only partly compensate for the dearth of private funding, unless it is accompanied by measures such as an exceptional large-scale issue of special drawing rights by the IMF. The benefits of this financing will also depend on the conditions attached to the use of Fund resources, an issue on which some progress has been made, although more remains to be done. The lack of private-sector financing will particularly affect certain large private-sector firms with an obvious need to roll over debt.

The Latin American economies went into the crisis with greater strengths than in the past, but these are more modest than has been claimed in some optimistic studies on the handling of the recent economic boom. With some striking exceptions, Chile chief among them, fiscal policies have remained procyclical. In most of the countries, furthermore, there has been a tendency for the current account to deteriorate, a process exacerbated in many cases by currency appreciation. Lower external borrowing by the public sector and the decision to absorb the flood of external financing by building up reserves are the two key elements of this new-found strength and are a departure from the way economic upturns were handled in the past. We do not yet know how much scope they really offer for adopting countercyclical macroeconomic policies during the crisis that is beginning. Hitherto, 
the only really definite development has been the rapid correction of the acute overvaluation of certain currencies in the region.

The crises of the past indicate that real currency depreciation is an opportunity to diversify the production structure. It may in fact be the most important of the opportunities offered by the current situation, and it should thus be actively pursued by applying production development policies.

Regional markets also offer an opportunity for diversification, a kind of "import substitution" in the region as a whole rather than in individual countries. However, opportunities of this kind will depend on other factors. In recent decades, intraregional trade has in fact been highly procyclical and integration efforts are going through a period of weakness or even crisis. Furthermore, major differences in respect of exchange-rate adjustments within current integration agreements could, in combination with individual protection measures, actually exacerbate the difficulties these efforts are currently facing.

There is now greater scope than in the past to apply countercyclical fiscal and monetary policies, and sparing use has begun to be made of these, but this scope is still limited. It will undoubtedly relieve countries of the need to adopt overly restrictive policies, with the exception of some whose handling of the economic boom was markedly procyclical. In summary, Latin America is better prepared than on other occasions, but this will serve to mitigate only some of the effects of the worst crisis the world economy has experienced since the Great Depression.

(Original: Spanish)

\section{Bibliography}

Bordo, Michael and others (2001), "Is the crisis problem growing more severe?", Economic Policy, vol. 16, No. 32, Oxford, Blackwell Publishing, April.

Bustillo, Inés and Helvia Velloso (2009), "The global financial crisis: what happened and what's next", Washington, D.C., ECLAC office in Washington, D.C., January.

Calvo, Guillermo (2008), "La super-crisis subprime: claves para entenderla y navegarla", document presented at the Andean Development Corporation Workshop "La crisis financiera global y su impacto en América Latina", Caracas, 1 December.

ECLAC (Economic Commission for Latin America and the Caribbean) (2009), La reacción de los gobiernos de América Latina y el Caribe frente a la crisis internacional: una presentación sintética de las medidas de política anunciadas hasta el 30 de enero de 2009, Santiago, Chile, 30 January.

(2008a), Structural change and productivity growth, 20 years later: old problems, new opportunities (LC/G.2367(SES.32/3)), Santiago, Chile.

(2008b), Economic Survey of Latin America and the Caribbean 2007-2008, Santiago, Chile. United Nations publication, Sales No. E.08.II.G.2.

(2008c), Preliminary Overview of the Economies of Latin America and the Caribbean 2008 (LC/G.2401-P), Santiago, Chile. United Nations publication, Sales No. E.08.II.G.2.

IDB (Inter-American Development Bank) (2008), All That Glitters May Not Be Gold: Assessing Latin America's Recent Macroeconomic Performance, Washington, D.C., Research Department, April.

IIF (Institute of International Finance) (2009), “Capital flows to emerging market economies" [online] http://www.iif.com, 27 January.

IMF (International Monetary Fund) (2009), World Economic Outlook Update [online] http://www.imf.org, 28 January.
Izquierdo, Alejandro, Randall Romero and Ernesto Talvi (2008), "Business Cycles in Latin America: The Role of External Factors”, Washington, D.C., Inter-American Development Bank/CERES, February.

Jara, Alejandro and Camilo E. Tovar (2008), "Monetary and financial stability implications of capital flows in Latin America and the Caribbean”, BIS Papers, No. 43, Basel, Bank for International Settlements, November.

Jiménez, Juan Pablo and Varinia Tromben (2006), "Fiscal policy and the commodities boom: the impact of higher prices for non-renewables in Latin America and the Caribbean", CEPAL Review, No. 90 (LC/G.2323-P), Santiago, Chile, December.

J.P. Morgan (2009), Emerging Markets Outlook and Strategy, 12 January.

(2008), "Determinants of Mexico's remittances from the U.S.", Global Data Watch, 17 October.

Kindleberger, Charles P. and Robert Aliber (2005), Manias, Panics, and Crashes: A History of Financial Crises, New York, John Wiley and Sons.

Minsky, Hyman P. (1982), "The financial instability hypothesis: a restatement", Can "It" Happen Again? Essays on Instability and Finance, Armonk, New York, M.E. Sharpe.

Ocampo, José Antonio (2007), "The macroeconomics of the Latin American economic boom", CEPAL Review, No. 93 (LC/G.2347-P), Santiago, Chile, December.

Ocampo, José Antonio and Maria Ángela Parra (2003), "The terms of trade for commodities in the twentieth century", CEPAL Review, No. 79 (LC/G.2200-P), Santiago, Chile, April.

Ocampo, José Antonio and Camilo E. Tovar (2008), "External and domestic financing in Latin America: developments, sustainability and financial stability implications", document presented at the Workshop on debt finance and emerging issues in financial integration, New York, April. 
Ratha, Dilip, Sanket Mohapatra and Zhimei Xu (2008), “Outlook for remittance flows 2008-2010: growth expected to moderate significantly, but flows to remain resilient", Migration and Development Brief, No. 8, Washington, D.C., World Bank, 11 November.

United Nations (2009), World Economic Situation and Prospects 2009, New York, January.
Von Braun, Joachim (2007), "The world food situation: new driving forces and required actions", Food Policy Report, Washington, D.C., International Food Policy Research Institute, December.

World Bank (2009), Global Economic Prospects 2009: Commodities at the Crossroads, Washington, D.C. 